Research Paper

\title{
Redox Regulation of Ephrin/Integrin Cross-Talk
}

\section{Francesca Buricchi $1, \dagger$ \\ Elisa Giannoni $1, \dagger$ \\ Giovanna Grimaldi ${ }^{1}$ \\ Matteo Parri ${ }^{1}$ \\ Giovanni Raugei ${ }^{2}$ \\ Giampietro Ramponi ${ }^{2}$ \\ Paola Chiarugi ${ }^{2}{ }^{*}$}

'Department of Biochemical Sciences; ${ }^{2}$ Center for Research, Transfer and High Education "Study at molecular and clinical level of chronic, inflammatory, degenerative and neoplastic disorders for the development of novel therapies"; University of Florence; Florence, Italy

tThese authors contributed equally to this work.

*Correspondence to: Paola Chiarugi; Dipartimento di Scienze Biochimiche; Viale Morgagni 50; Firenze 50134 Italy; Tel.: 39.055.41376; Fax: 39.055.4222725 E-mail: paola.chiarugi@unifi.it

Original manuscript submitted: 11/28/06

Revised manuscript submitted: 01/25/07

Manuscript accepted: 01/29/07

Previously published online as a Cell Adhesion \& Migration E-publication:

http://landesbioscience.com/journals/celladhesion/article/3911

\section{KEY WORDS}

EphA2 kinase, reactive oxygen species, integrin, cell repulsion, tumorigenesis

\section{ABBREVIATIONS}

DCF-DA 2',7'-dichlorofluorescein diacetate

FN fibronectin

ECM extracellular matrix

GAP GTPase activating protein

GEF GTPase exchange factor

GF growth factor

5-LOX 5-lypoxigenase

RTK receptor tyrosine kinase

PTP protein tyrosine phosphatase

EGF epidermal growth factor

ROS reactive oxygen species

LMW-PTP low molecular weight-phosphotyrosine phosphatase

\section{ABSTRACT}

Interactions linking the Eph receptor tyrosine kinase and ephrin ligands transduce short-range repulsive signals regulating several motile biological processes including axon path-finding, angiogenesis and tumor growth. These ephrin-induced effects are believed to be mediated by alterations in actin dynamics and cytoskeleton reorganization. The members of the small Rho GTPase family elicit various effects on actin structures and are probably involved in Eph receptor-induced actin modulation. In particular, some ephrin ligands lead to a decrease in integrin-mediated cell adhesion and spread. Here we show that the ability of ephrinAl to inhibit cell adhesion and spreading in prostatic carcinoma cells is strictly dependent on the decrease in the activity of the small GTPase Racl. Given the recognized role of Rac-driven redox signaling for integrin function, reported to play an essential role in focal adhesion formation and in the overall organization of actin cytoskeleton, we investigated the possible involvement of oxidants in ephrinA1/EphA2 signaling. We now provide evidence that Reactive Oxygen Species are an integration point of the ephrinA 1 /integrin interplay. We identify redox circuitry in which the ephrinA 1 -mediated inhibition of Racl leads to a negative regulation of integrin redox signaling affecting the activity of the tyrosine phosphatase LMW-PTP. The enzyme in turn actively dephosphorylates its substrate p190RhoGAP, finally leading to RhoA activation. Altogether our data suggest a redox-based Rac-dependent upregulation of Rho activity, concurring with the inhibitory effect elicited by ephrinA 1 on integrin-mediated adhesion strength.

\section{INTRODUCTION}

Integrins are heterodimeric glycoproteins that bind to extracellular matrix (ECM) ligands and transmit signals that inhibit apoptosis, regulate the progression through the $\mathrm{G}_{1}$ phase of the cellular cycle, and promote adhesion or migration. ${ }^{1-4}$ In non-transformed cell lines the disruption of this connection to the extracellular matrix has deleterious effects on cell survival, causing a peculiar type of apoptosis called anoikis. ECM-engaged integrins elicit signals which mostly overlap those activated from receptor tyrosine kinases (RTKs) that bind soluble growth factors and cytokines. However, integrated cross-talk between integrins and RTK signaling is necessary for cell proliferation, survival and migration. The integration between integrin and RTK signaling is mainly carried out at two levels: (1) a direct interaction between integrins and membrane receptors that amplify signaling through mechanisms that involve posttranslational modifications and integrin structural changes leading to activation; and (2) the activation of intracellular soluble messengers that can be commonly regulated by integrins and RTKs.

Much evidence supports the idea that Reactive Oxygen Species (ROS) act as second messengers modulating the activity of signaling proteins upon growth factor and cytokine stimulation. They are generated after integrin engagement in a Rac1-dependent manner and these oxidant intermediates play an instrumental role in integrin signaling during fibroblast adhesion and spreading, acting on redox-sensitive substrates such as phosphotyrosine phosphatases, namely Low Molecular Weight-Protein Tyrosine Phosphatase (LMW-PTP) ${ }^{5}$ and Src Homology-2 Phosphatase (SHP2). ${ }^{6}$ It has been reported that integrin activation is joined to a Rac-dependent generation of ROS specifically acting on target proteins such as LMW-PTP, ${ }^{5} \mathrm{SHP}^{6}$ and other cytoskeletal proteins. ${ }^{7-8}$ The reversible oxidation of these proteins has a profound effect on cell spreading onto ECM, through indirect activation of both Focal Adhesion Kinase and the small GTPase Rho, thus suggesting that ROS act as second messengers in the cytoskeletal organization in response to integrin engagement. ${ }^{9-11}$ 
Eph receptors have been reported as a family of RTKs strongly influencing cell adhesion and migration and are therefore indicated as regulators of integrin activity. Eph receptors and their ligands, ephrins, are involved in the establishment of organ boundaries, cell shape and positioning, angiogenesis and repulsive guidance of cell migration during development. Differently from most RTKs, whose activation sustains cell proliferation, Ephs elicit anti-proliferative and de-adhesive responses. In particular, activation of endogenous EphA2 kinase induces an inactive conformation of integrins, inhibits cell spreading, migration, integrin-mediated adhesion ${ }^{12}$ and induces cell rounding and retraction fiber formation. ${ }^{13}$ The reorganization of cell morphology during adhesion and detachment is mainly regulated by signals derived from cell adhesion receptors and requires the disruption of focal adhesion complexes and reorganization of the actin/myosin cytoskeleton. In this process members of the Rho family of small GTPases exert a key role. ${ }^{14}$ Several recent reports indicate that GTPases are engaged in a signal transduction cascade elicited by Ephs; for instance the small GTPase Rho is involved in EphA receptor-induced cytoskeleton remodelling and increase in acto-myosin contraction. ${ }^{15-17}$ In addition Rac1 GTPase has been involved in ephrinA1-induced inhibition of vascular smooth cell spreading ${ }^{18}$ and R-Ras is inactivated through both phosphorylation and increased GTP hydrolysis during ephrinB-mediated inhibition of cell-matrix adhesion. ${ }^{19}$

In this paper we provide evidence that ROS are an integration point of the ephrinA1/integrin interplay. We propose that the ephrinA1-mediated inhibition of Rac1 leads to a down-regulation of integrin redox signaling, affecting the activity of LMW-PTP. The activated tyrosine phosphatase in turn dephosphorylates its substrate p190RhoGAP, finally leading to RhoA activation, cell rounding and de-adhesion from ECM.

\section{MATERIAL AND METHODS}

Materials. Unless specified, all reagents were obtained from Sigma. PC3 cells were from ATCC; recombinant mouse $\mathrm{Fc}_{\mathrm{c}}$ and ephrinA1-Fc chimera were from R \& D Systems, anti-phosphotyrosine (clone 4G10) and anti-EphA2 antibodies were from Upstate Biotechnology Inc., anti-p190Rho-GAP, anti-Rac1 antibodies and the Rho GTPase assay kit were from Becton Dickinson, anti-RhoA antibodies were from Santa Cruz Biotechnology, rabbit anti-LMW-PTP antibodies were obtained from our Department. LMW-PTP siRNA (5'-AAGTCCGTGCTGTTTGTGTGT-3') and a negative control siRNA sequence corresponding to nucleotides 695-715 of the firefly luciferase (U31240) were obtained from Qiagen. Wild type and mutant Rac1 (wt, N17 and V12) were a gift of Dr. C. Deroanne (University of Marseille).

Cell culture, stimulation, RNA interfering protein overexpression. PC3 prostatic carcinoma cells were cultured in Ham's F12 medium supplemented with $10 \%$ fetal calf serum in $5 \% \mathrm{CO}_{2}$ humidified atmosphere. For studies using soluble ephrinA1, cells in the logarithmic growth phase were always stimulated with $1 \mu \mathrm{g} \mathrm{ml}{ }^{-1} \mathrm{Fc}$ or ephrinA1-Fc for the indicated times. PC3 cells were transiently transfected using Lipefectamine 2000 (Invitrogen) as described by the manufacturer. Cells were transfected with $4 \mu \mathrm{g}$ of siRNA or RacV12, RacN17, Racwt plasmid DNA per $60 \mathrm{~mm}$ dish. siRNA efficiency was tested by anti-LMW-PTP immunoblot: although at 48 hours we detected an appreciable inhibition of LMW-PTP expression, the best efficiency was observed $72 \mathrm{~h}$ after transfection. Rac wt and mutant efficiency of transfection were tested by anti-Rac1 immunoblot after
$48 \mathrm{~h}$ of transfection. Protein content was evaluated by Bradford assay and normalized for each experiment.

Integrin-mediated cell adhesion assay. $10^{6}$ cells were serum-starved for $24 \mathrm{~h}$ before detaching with $0.25 \%$ trypsin for $1 \mathrm{~min}$. Trypsin was blocked with $0.5 \mathrm{mg} / \mathrm{ml}$ soybean trypsin inhibitor, and cells were resuspended in $3 \mathrm{ml} / 10 \mathrm{~cm}$ dish of fresh medium, maintained in suspension for 30 minutes at $37^{\circ} \mathrm{C}$, and then directly seeded onto precoated dishes treated overnight with $10 \mu \mathrm{g} / \mathrm{ml}$ human fibronectin. Control cells were kept in suspension by plating them onto dishes pretreated with $1 \mathrm{mg} / \mathrm{ml}$ of polylysine in culture medium, thus preventing adhesion to the dish.

Immunoprecipitation and Western blot analysis. One x $10^{6}$ cells were lysed for 20 min on ice in $500 \mu \mathrm{l}$ of complete RIPA lysis buffer (50 mM Tris- $\mathrm{HCl}, \mathrm{pH} 7.5,150 \mathrm{mM} \mathrm{NaCl}, 1 \%$ Nonidet P-40, $2 \mathrm{mM}$ EGTA, $1 \mathrm{mM}$ sodium orthovanadate, $1 \mathrm{mM}$ phenyl-methanesulphonyl-fluoride, $10 \mu \mathrm{g} / \mathrm{ml}$ aprotinin, $10 \mu \mathrm{g} / \mathrm{ml}$ leupeptin). Lysates were clarified by centrifuging and were immunoprecipitated for $4 \mathrm{~h}$ at $4^{\circ} \mathrm{C}$ with 1-2 $\mu \mathrm{g}$ of the specific antibodies. We used either anti-EphA2 antibodies or $1 \mu \mathrm{g} \mathrm{ml}-1$ ephrinA1-Fc fusion protein for anti-EphA2 immunoprecipitation. Immune complexes were collected on protein A Sepharose, separated by SDS/PAGE, and transferred onto PVDF. The immunoblots were incubated in $1 \%$ bovine serum albumin, $10 \mathrm{mM}$ Tris/ $\mathrm{HCl} \mathrm{pH} \mathrm{7.5,} 1 \mathrm{mM}$ EDTA and 0.1\% Tween-20, for $1 \mathrm{~h}$ at room temperature, and were probed first with specific antibodies, then with secondary antibodies. Quantity-One software (Biorad) was used to perform quantitative analyses.

In vitro three-dimensional migration assay. The in vitro motility assays were performed using the Transwell system of Costar, equipped with $8-\mu \mathrm{m}$ pore polyvinylpirrolidone-free polycarbonate filters (diameter, $13 \mathrm{~mm}$ ). Cells were loaded into the upper compartment $\left(5 \times 10^{5}\right.$ cells in $\left.500 \mu \mathrm{l}\right)$ in serum-deprived growth medium, with or without $1 \mu \mathrm{g} \mathrm{ml}-1$ of ephrinA1-Fc. The upper chambers were placed into 6-well culture dishes containing $1 \mathrm{ml}$ of medium with $50 \mathrm{ng} / \mathrm{ml}$ human EGF as chemoattractant. After $24 \mathrm{~h}$ of incubation at $37^{\circ} \mathrm{C}$, non-invading cells were removed mechanically using cotton swabs, and the microporous membrane containing the invaded cells was stained with DiffQuick solution (Medion Diagnostics). Chemotaxis was evaluated by counting the cells that had migrated to the lower surface of the polycarbonate filters. For each filter the number of cells in ten randomly chosen fields was determined, and the average was then calculated (mean \pm S.D.).

Assay of intracellular $\mathrm{H}_{2} \mathrm{O}_{2}$. Intracellular production of $\mathrm{H}_{2} \mathrm{O}_{2}$ was assayed as previously described. ${ }^{20}$ Five minutes before the end of the incubation time, cells were treated with $5 \mu \mathrm{g} / \mathrm{ml} 2^{\prime}, 7^{\prime}$-dichlorofluorescein diacetate (DCF-DA). After PBS washing, cells were lysed in $1 \mathrm{ml}$ of RIPA buffer and analyzed immediately by fluorimetric analysis at $510 \mathrm{~nm}$. Data have been normalized on total protein content.

Determination of Rac1 activity. $10^{6}$ PC3 cells were directly lysed in RIPA buffer, the lysates were clarified by centrifugation and Rac1-GTP was quantified. Briefly, lysates were incubated with $10 \mu \mathrm{g}$ of p21 activated kinase (PAK)-GST fusion protein absorbed on glutathione-Sepharose beads. Immunoreactive Racl precipitated by PAK-GST was then quantified by anti-Rac1 western blot analysis. Lysates were normalized for Rac1 content by anti-Rac1 immunoblot.

Determination of RhoA activity. $10^{6}$ PC3 cells were directly lysed in RIPA buffer, the lysates were clarified by centrifugation and RhoA-GTP was quantified using the specific assay kit from Becton Dickinson, according to the manufacturer's instructions. Briefly, lysates were incubated with $10 \mu \mathrm{g}$ of Rhotekin-Rho binding 


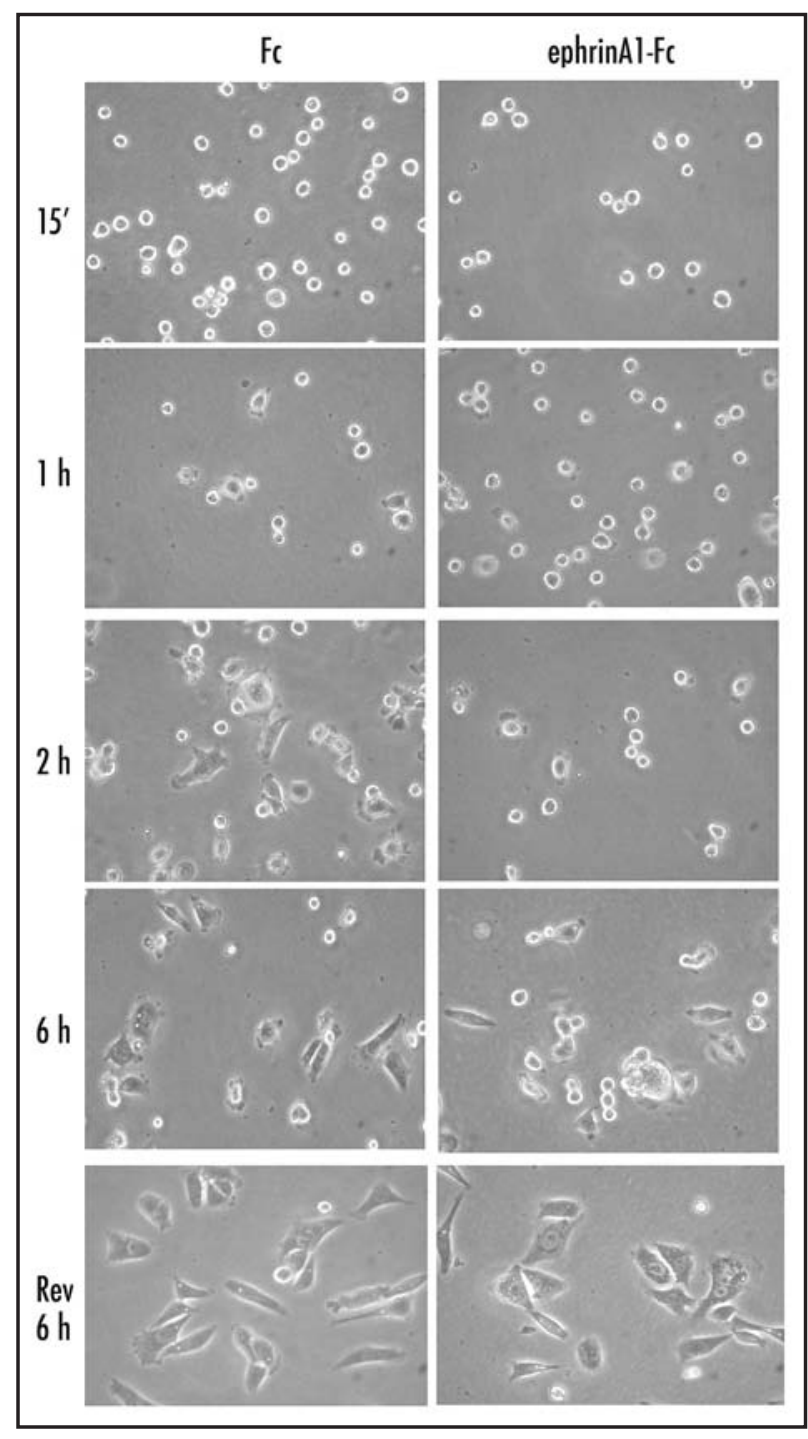

Figure 1. EphrinA1-Fc treatment inhibits adhesion and spreading of PC3 cells. Twenty-four hours after starvation, PC3 cells were detached and presuspended for 30 minutes in serum-free medium. Cells were stimulated with ephrinA 1-Fc or $\mathrm{Fc}_{\mathrm{c}} 1 \mu \mathrm{g} / \mathrm{ml}$ and allowed to adhere to $\mathrm{FN}$-coated dishes $(10 \mu \mathrm{g} / \mathrm{ml})$ for the indicated times and then were observed under a phase contrast microscope. After 6 hours of adhesion cells were detached with trypsinization and replated onto $\mathrm{FN}$-coated dishes in serum-free medium; photographs were taken after 6 hours of adhesion.

domain fusion protein absorbed on glutathione-Sepharose beads. Immunoreactive RhoA precipitated by Rhotekin-GST was then quantified by anti-RhoA Western blot analysis. Lysates were normalized for RhoA content by anti-RhoA immunoblot.

In vivo 5'-fluoresceinated-iodoacetamide (5'-F-IAA) labelling. Suspended and adherent PC3 cells were lysed in RIPA buffer in which 5'-F-IAA was added from freshly prepared stock to a final concentration of $5 \mu \mathrm{M}$. The lysates were maintained for $10 \mathrm{~min}$ at $37^{\circ} \mathrm{C}$ for the labeling step and then were treated for immunoprecipitation with anti-LMW-PTP antibodies. Reduced protein sulfidryls were assayed by anti-fluorescein immunoblot.

LMW-PTP activity assay. The tyrosine phosphatase activity was measured as previously reported. ${ }^{21}$ Briefly, cells were lysed in RIPA buffer and LMW-PTP was immunoprecipitated from lysates. Immunoprecipitates were then resuspended in $100 \mu \mathrm{l}$ of $0.1 \mathrm{M}$ sodium acetate, $\mathrm{pH}$ 5.5, $10 \mathrm{mM}$ EDTA. Phosphatase activity assay

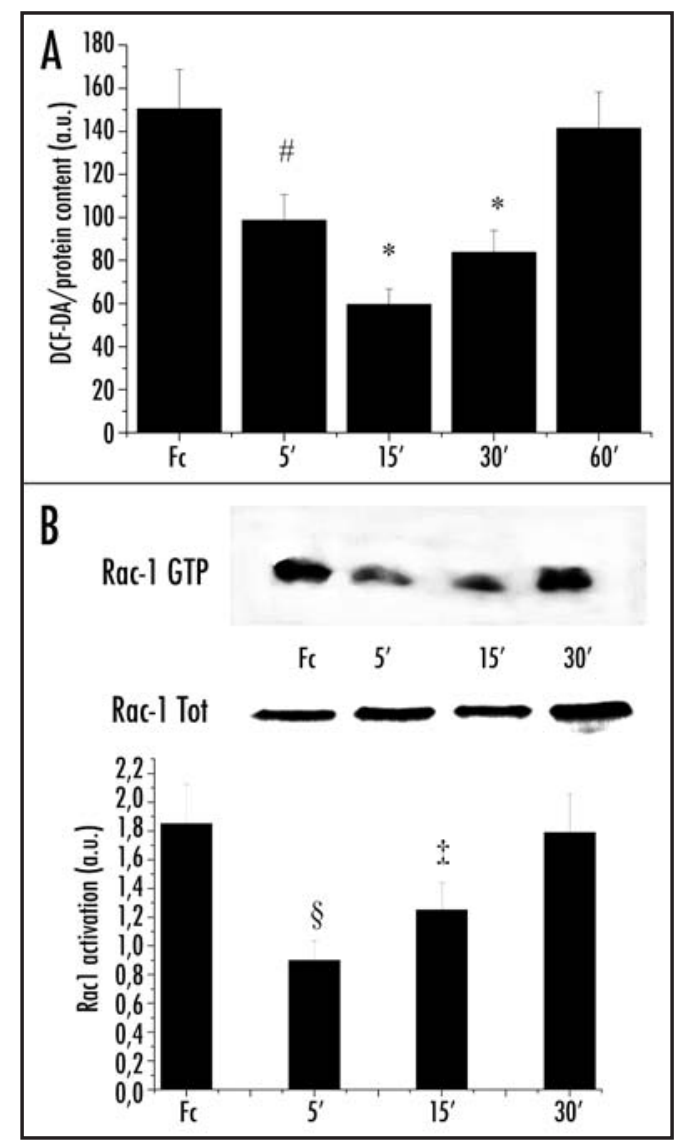

Figure 2. EphrinA1-induced decrease in intracellular hydrogen peroxide content is Rac-dependent: (A) ROS content measurement: $1 \times 10^{6}$ PC 3 cells were serum-starved for $24 \mathrm{~h}$ and then stimulated with $\mathrm{Fc}$ or ephrinA $1-\mathrm{Fc}$ for the indicated times. Hydrogen peroxide production was evaluated with 2',7'-dichlorofluorescein diacetate (DCF-DA). Five minutes before the end of ephrinA 1-Fc stimulation, cells were treated with $5 \mu \mathrm{g} / \mathrm{ml}$ DCF-DA. After PBS washing, cells were lysed in $1 \mathrm{ml}$ of RIPA buffer and analyzed immediately by fluorescence spectrophotometric analysis at $510 \mathrm{~nm}$. Data were normalized on total protein content. Results are means $\pm S D$ of four independent experiments. ${ }^{\#} p<0.005$ vs Fc; ${ }^{*} p<0.001$ vs Fc. (B) Rac activity after ephri$\mathrm{nA}$ 1-Fc stimulation: $1 \times 10^{6}$ PC 3 cells were treated as in A and Rac-GTP was analyzed by a pull-down assay performed with PAK-GST-agarose beads. The total amount of Rac-1 was then quantified by anti-Rac immunoblot. The mean ratio between the two values obtained from three independent experiments and SD are reported in the plot. $\S_{p}<0.01$ vs Fc; $\ddagger_{p}<0.05$ vs Fc.

was performed by adding $100 \mu \mathrm{l}$ of $10 \mathrm{mM}$ p-nitrophenyl phosphate (PNPP) at $37^{\circ} \mathrm{C}$ for $1 \mathrm{~h}$. The production of $\mathrm{p}$-nitrophenol was measured colorimetrically at $410 \mathrm{~nm}$. The results were normalized on the basis of LMW-PTP content analyzed by anti-LMW-PTP immunoblot.

\section{RESULTS}

ephrinA1 induces a delay in adhesion and inhibits cell spreading. In a recent paper we reported that in PC3 cells, a human prostatic carcinoma cell line highly expressing EphA2, ephrinA1 stimulation causes cell body rounding and retraction fiber formation. In addition, cell adhesion on ephrinA1-coated slides is slowed and spreading inhibited. ${ }^{13}$ To further confirm that ephrinA1 influences integrin-dependent cell adhesion and spreading, PC 3 cells were allowed to adhere to fibronectin (FN)-coated dishes during ephrinA1 


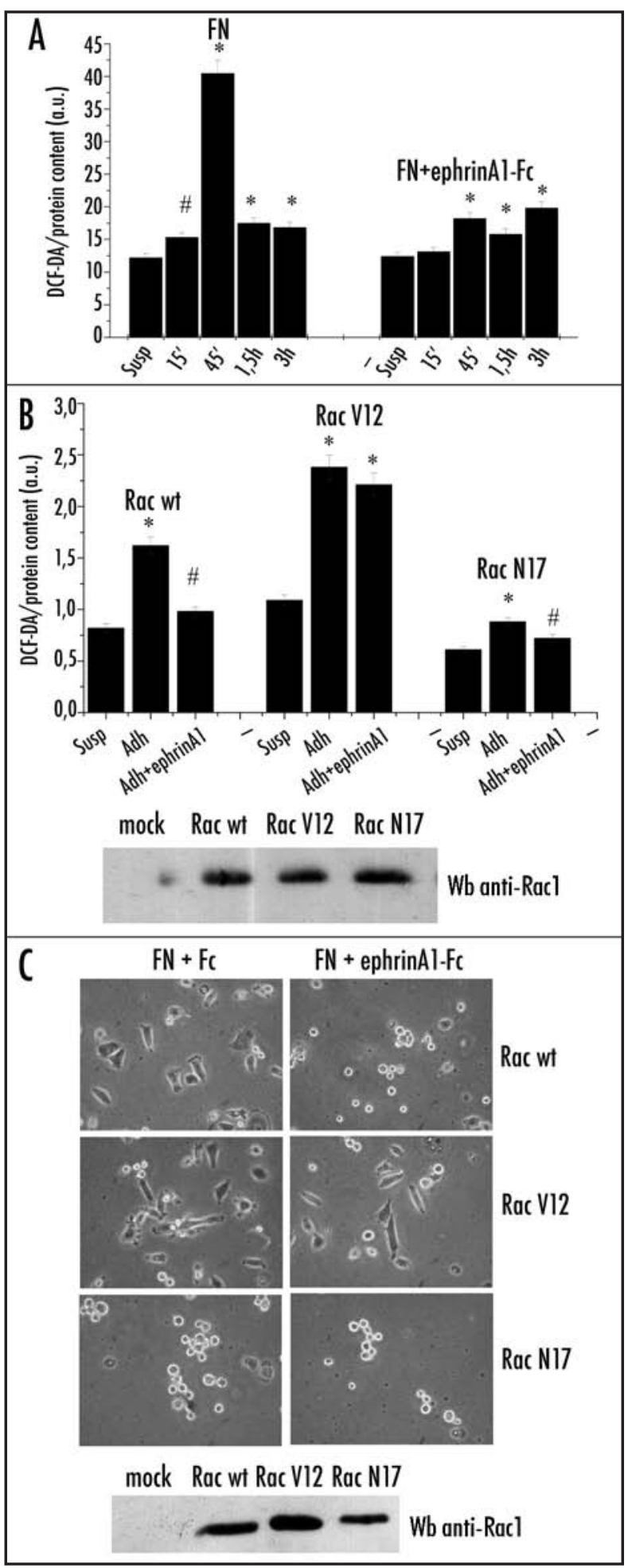

stimulation. The results evidence that ephrinA1 induces a dramatic delay in cell adhesion and spreading upon ECM contact (Fig. 1). The inhibition of integrin-mediated cell adhesion elicited by ephrinA1 is reversible since ephrinA1-treated cells, after re-seeding onto fresh FN-coated dishes, regain the capability to properly adhere and spread (Fig. 1).

ephrinA1 stimulation inhibits integrin-dependent $\mathrm{H}_{2} \mathrm{O}_{2}$ generation. Integrin engagement is recognized as being linked to a transient increase in intracellular hydrogen peroxide, which exerts
Figure 3. EphrinAl inhibits integrin-dependent hydrogen peroxide generation. (A) Evaluation of hydrogen peroxide during adhesion in concomitance with ephrinA1-Fc stimulation. Twenty-four hours after starvation PC3 cells were detached, presuspended for 30 minutes in serum-free medium and kept in suspension or seeded onto fibronectin (FN)-coated dishes in the presence or not of $1 \mu \mathrm{g} / \mathrm{ml}$ ephrinA 1-Fc for the indicated times. Hydrogen peroxide production was measured as in Figure 2. Results are means \pm SD of four independent experiments. ${ }^{\#} p<0.005$ vs suspension; ${ }^{*} p<0.001$ vs suspension (B) Rac-1 regulates ephrinA 1 -dependent inhibition of integrin-mediated hydrogen peroxide generation. Rac wt, Rac V12 (constitutive active mutant) and Rac N17 (dominant negative) were overexpressed in PC3 cells. After 24 hours of starvation, PC3 were detached, presuspended for $30 \mathrm{~min}$ utes in serum-free medium and kept in suspension or plated onto $\mathrm{FN}$-coated dishes for 45 minutes in the presence or not of ephrinA 1-Fc. ROS production was measured as in Figure 2. Means and SD of four independent experiments are indicated in the graph. ${ }^{\#} p<0.005$ vs suspension; ${ }^{*} p<0.001$ vs suspension. Transfection efficiency of Rac mutants was evaluated by Western blot. (C) Rac-1 regulates ephrinA 1-dependent inhibition of integrin-mediated cell adhesion. Rac wt, Rac V12 and Rac N17 expressing plasmids were overexpressed in PC3 cells. After 24 hours of starvation, the cells were detached, presuspended for 30 minutes in serum-free medium and plated onto FN-coated dishes in the presence or not of ephrinA 1-Fc. Photographs were taken with a phase contrast microscope at the end of the adhesion time. Transfection efficiency of Rac mutants was evaluated by Western blot.

a key role on cell adhesion. ${ }^{5,10,22}$ Given the inhibitory effect of ephrinA1 on integrin function, inducing a delay in cell adhesion and an inhibition of cell spread, we speculated that the cross-talk between integrin and Ephs could be mediated by hydrogen peroxide. The evaluation of ROS content reveals that the amount of intracellular $\mathrm{H}_{2} \mathrm{O}_{2}$ rapidly decreases after ephrinA1 stimulation, later returning to basal level (Fig. 2A).

The small GTPase Racl mediates ligand-dependent generation of ROS in a variety of physiological settings through modulation of oxygen radical sources. ${ }^{23,24}$ Although the effect of Rac1 regulation by ephrins is still debated, there is a large body of evidence that Eph activation leads to Rac1 inhibition. ${ }^{17,25}$ In agreement with these previous reports, we observed an early decrease in GTP-bound (i.e., active) Rac1 upon ephrinA1 stimulation, paralleling the decline in $\mathrm{H}_{2} \mathrm{O}_{2}$ content (Fig. 2B)

To evaluate whether ephrinA1 inhibition of integrin-mediated adhesion could be due to an ephrin-dependent modulation of $\mathrm{H}_{2} \mathrm{O}_{2}$, we measured $\mathrm{H}_{2} \mathrm{O}_{2}$ during FN contact. We observed that the peak of hydrogen peroxide production, corresponding to $45 \mathrm{~min}$ of adhesion, is completely abolished when adhesion is concomitant with ephrinA1 stimulation (Fig. 3A). We then provided evidence that the counteracting effect of ephrinA1 on integrin-dependent $\mathrm{H}_{2} \mathrm{O}_{2}$ generation is mediated by Rac1. We genetically modified Rac1 activity through transfection of the constitutive active $\mathrm{RacV} 12$ and the dominant negative RacN17. We observed that cells overexpressing RacV12 are insensitive to the inhibition of $\mathrm{H}_{2} \mathrm{O}_{2}$ production induced by ephrinA1, while the overexpression of Rac N17 also inhibits the adhesion-dependent production of $\mathrm{H}_{2} \mathrm{O}_{2}$ (Fig. 3B). In keeping we observed that modulation of $\mathrm{H}_{2} \mathrm{O}_{2}$ production through the overexpression of Rac mutants similarly influences cell adhesion and spreading (Fig. 3C).

To further confirm the role of ROS in ephrin-induced inhibition of cell adhesion and spreading, we exogenously modulated the intracellular ROS content using antioxidants such as Nor-dihydroguaiaretic acid (NDGA) and N-acetylcysteine (NAC). NAC is a general scavenger of oxidant species, while NDGA specifically inhibits 5-lipoxygenase (5-LOX), the cytosolic oxidase that is mainly involved in $\mathrm{H}_{2} \mathrm{O}_{2}$ 


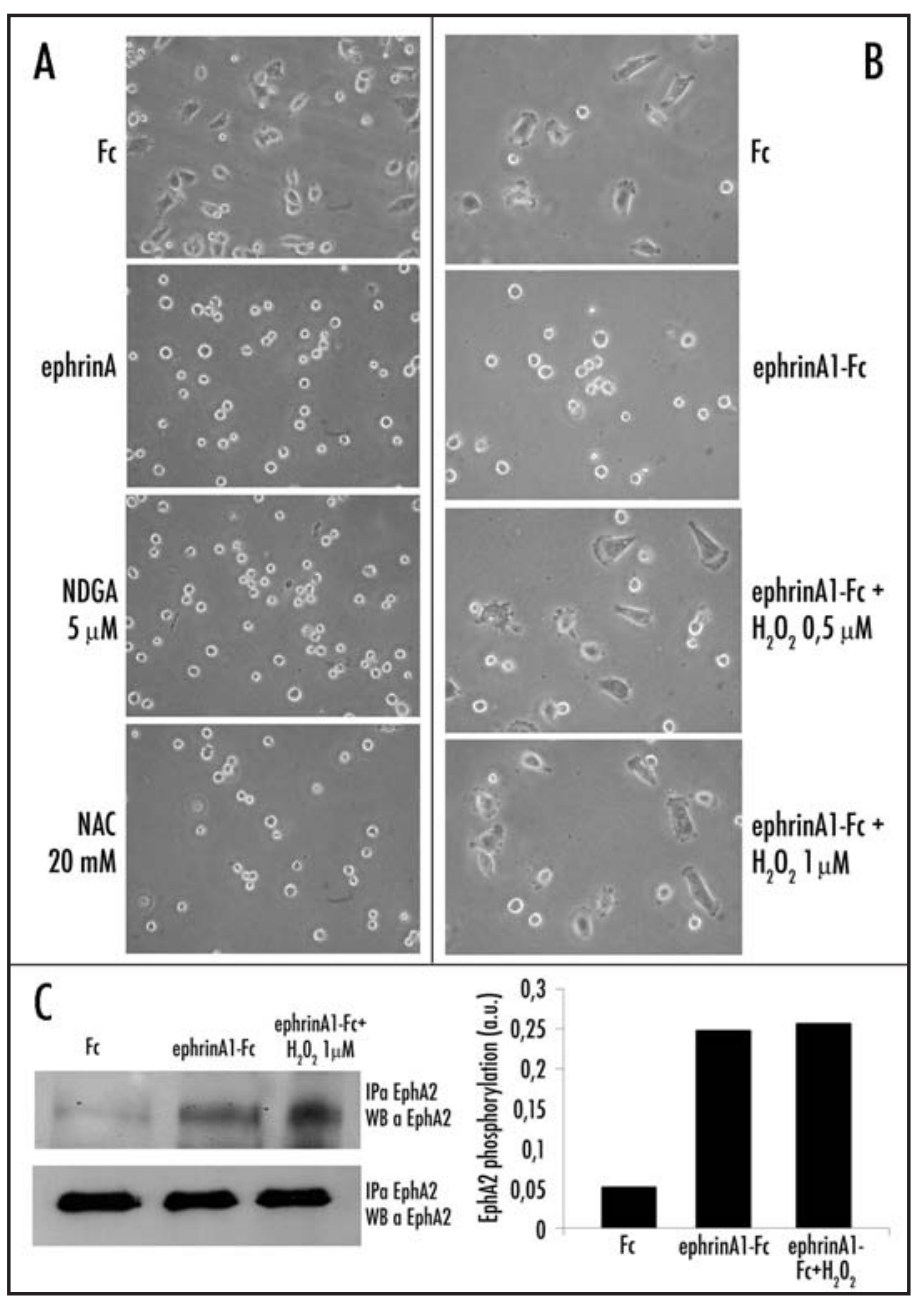

Figure 4. Antioxidant and $\mathrm{H}_{2} \mathrm{O}_{2}$ treatment influences ephrinAl-dependent inhibition of cell adhesion and spreading. (A) Effect of antioxidant treatment: $24 \mathrm{~h}$ after starvation PC3 cells have been detached and presuspended for 30 minutes in serum-free medium. Cells were then treated with 20 mM NAC and $5 \mu \mathrm{MNDGA}$ or stimulated with ephrinA $1-\mathrm{Fc}$ and then allowed to adhere to $\mathrm{FN}$-coated dishes for 45 minutes. Afterward the cells were observed under a phase contrast microscope (B) Effect of hydrogen peroxide treatment. Cells were treated as in A except that before adhesion they were treated with hydrogen peroxide at the indicated doses and/or with ephrinAl-Fc $1 \mu \mathrm{g} / \mathrm{ml}$. After 45 minutes of adhesion, photographs were taken under a phase contrast microscope. (C) Activation of EphA2 induced by stimulation with ephrinA1-Fc or a mixture of ephrinA 1-Fc plus hydrogen peroxide. In order to exclude that the effect of oxidant treatment could be due to ligand inactivation we stimulated PC3 cells with ephrinA 1-Fc or with a previously prepared mixture of ephrinA $1-\mathrm{Fc}_{\mathrm{c}} 1 \mu \mathrm{g} / \mathrm{ml} / \mathrm{H}_{2} \mathrm{O}_{2} 1 \mu \mathrm{M}$ for 15 minutes. An IP with ephrinA 1-Fc was performed followed by Western blot with anti-phosphotyrosine-specific antibodies. The membrane was then stripped and reprobed with anti-EphA2 specific antibodies for normalization.

production after integrin engagement. ${ }^{5}$ Our results show that both antioxidants mimic the effect of ephrinAl stimulation, inducing cells to acquire a round-shape and inhibiting cell spreading (Fig. $4 \mathrm{~A})$. Control cells, in which integrin signaling through the proper increase in $\mathrm{H}_{2} \mathrm{O}_{2}$ production activates the mechanisms necessary for correct cytoskeleton organization, are normally able to spread in response to FN contact. We further treated adhering cells with physiological doses of $\mathrm{H}_{2} \mathrm{O}_{2}$ (similar to those produced during adhesion to FN). ${ }^{26,27}$ In the presence of $\mathrm{H}_{2} \mathrm{O}_{2}$ the effect of ephrinA1 is reversed and adhering cells spread correctly, thus confirming that the inhibitory effect of ephrinA1 on cell adhesion is actually due to down-regulation of $\mathrm{H}_{2} \mathrm{O}_{2}$ production (Fig. $4 \mathrm{~B}$ ). We have excluded ligand inactivation due to oxidation, as the ability of ephrinA1 to activate EphA2 is indeed unchanged by $\mathrm{H}_{2} \mathrm{O}_{2}$ pretreatment of the ligand (Fig. 4C).

Collectively, these results indicate that ephrinA1, by inducing a down-regulation of Rac1 activity, leads to modulation of intracellular $\mathrm{H}_{2} \mathrm{O}_{2}$ content. This decrease in $\mathrm{H}_{2} \mathrm{O}_{2}$ amount is correlated to the inhibition of cell spreading and to the preservation of round morphology.

ephrinA1/EphA2 redox signaling plays a pivotal role in the regulation of cell motility. Besides its role in the regulation of integrin signaling, we speculated that the modulation of $\mathrm{H}_{2} \mathrm{O}_{2}$ content by ephrinAl may be significant for the motility response induced by the repulsive factor. We therefore studied the effect of ephrinA1 on epidermal growth factor (EGF)-induced chemotaxis, during $\mathrm{H}_{2} \mathrm{O}_{2}$ or antioxidant treatments. $\mathrm{H}_{2} \mathrm{O}_{2}$ treatment strongly reverses the inhibitory effect of ephrinA1 on EGF-induced migration (Fig. 5A) while NAC or NDGA antioxidant treatments mimic ephrinA1-mediated inhibition of cell motility, and slightly synergize with ephrinA1 (Fig. 5B). The key role of Rac1 signaling in ephrinA1-mediated motility response is confirmed by analysis of EGF-induced migration in cells overexpressing either RacV12 or RacN17. Indeed, overexpression of the constitutive active RacV12 blocks the inhibitory effect of ephrinA1 on cell motility, while Rac N17 overexpression synergizes with ephrinA1-mediated inhibition of cell motility (Fig. 5C).

Low molecular weight-protein tyrosine phosphatase (LMW-PTP) is the molecular target of the redox-mediated cross-talk between EphA2 and integrins. The effect of the intracellular production of ROS is the reversible oxidation of many redox sensitive proteins. ${ }^{28}$ Thiols, for their ability to be reversibly oxidized, are recognized as key targets of $\mathrm{H}_{2} \mathrm{O}_{2}$. Redox sensitive proteins include PTPs, enzymes that possess one or two cysteines in the catalytic site that can be reversibly oxidized and inhibited by $\mathrm{H}_{2} \mathrm{O}_{2} \cdot{ }^{29-32}$ These proteins play a pivotal role in receptor tyrosine kinase (RTK) signal transduction, controlling their phosphorylation level, and therefore the activation of many downstream signaling molecules. Of the redox sensitive PTPs, we focused our attention on LMW-PTP, due to its involvement in both cytoskeleton rearrangement, acting on p190RhoGAP 9,11 and focal adhesion kinase, ${ }^{33}$ and in ephrinA1/EphA2 signaling regulation through the dephosphorylation of EphA2. ${ }^{13,34}$ We analyzed the redox state of LMW-PTP in ephrinA1 stimulated cells by selective carboxymethylation of reactive Thiols. ${ }^{21,35}$ Our results show that ephrinA1 induces an increase in the amount of reduced LMW-PTP, peaking at 15 min of stimulation, in agreement with the kinetics of $\mathrm{H}_{2} \mathrm{O}_{2}$ and Rac1 activity decline (Fig. 6A). The reduction of LMW-PTP thiols by ephrinA1/EphA2 signaling is paralleled by its transient enzymatic activation (Fig. 6B).

Furthermore, in agreement with our previous observations, ${ }^{5}$ LMW-PTP is oxidized during adhesion as a consequence of the strong ROS burst, but concomitant stimulation with ephrinA1 protects LMW-PTP from this modification, thus maintaining the phosphatase in its reduced/active state (Fig. 6C). The involvement of Rac1 in LMW-PTP redox regulation is confirmed by the results obtained with genetic manipulation of Racl activity: RacV12 overexpression prevents LMW-PTP reduction by ephrinA1/EphA2 signaling, while RacN17 prevents its oxidation in response to integrin signaling and enhances ephrinA1 response (Fig. 6C). 


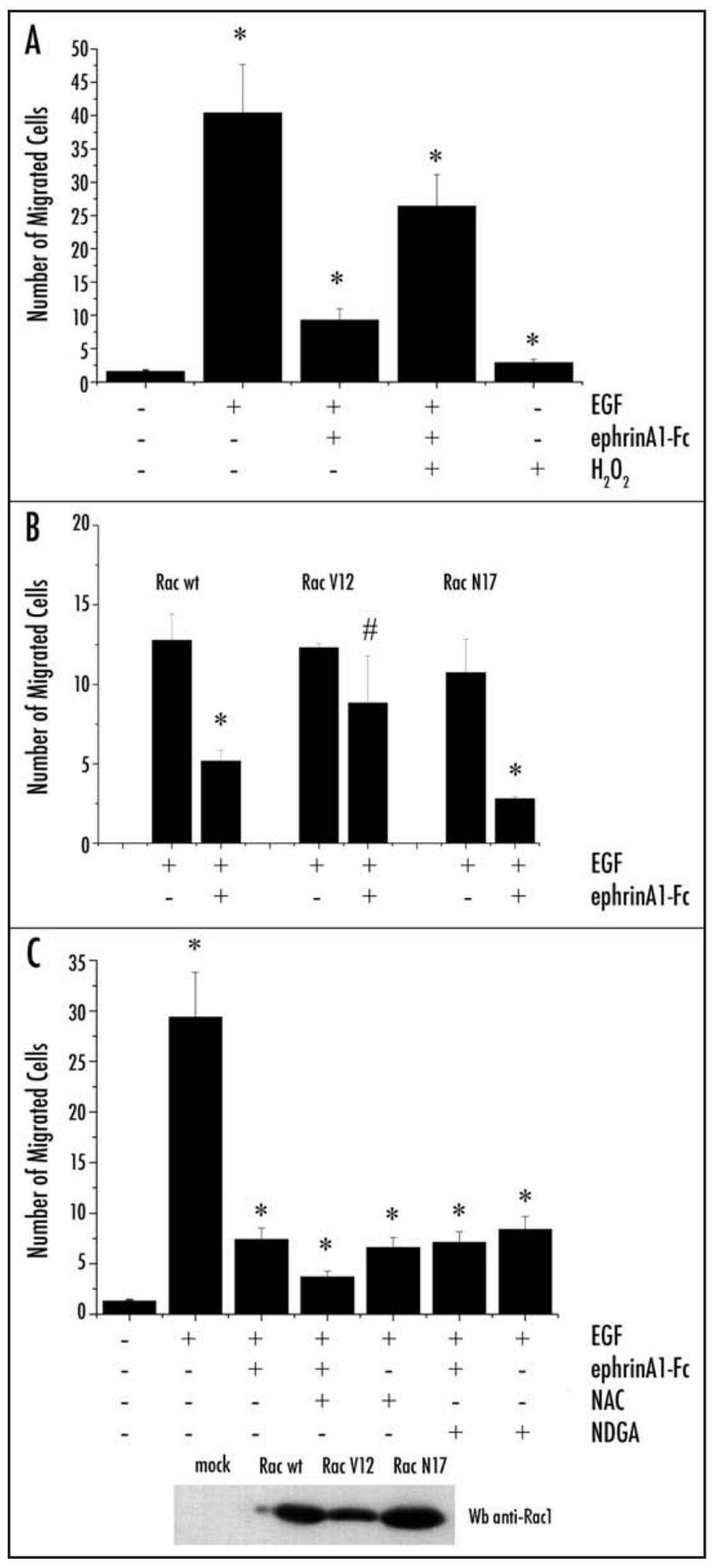

LMW-PTP redox regulation affects the tyrosine phosphorylation level of p190RhoGAP and Rho activation. Previous works have demonstrated that LMW-PTP is involved in cytoskeleton rearrangement through the regulation of p190RhoGAP phosphorylation, finally leading to activation of RhoA., ${ }^{9,11,36}$ Rho belongs to the family of small GTPases that, in response to several extracellular stimuli-including growth factors and integrins-control actin filament dynamics during important cellular events such as migration, adhesion and detachment. ${ }^{37-39}$ We therefore speculated that RhoA
Figure 5. EphrinA1-induced inhibition of PC3 cell migration depends on the intracellular redox state. Cells were loaded into the upper compartment $\left(5 \times 10^{5}\right.$ cells in $\left.500 \mu l\right)$ in serum-deprived growth medium, with or without $1 \mu \mathrm{g} / \mathrm{ml}$ of ephrinAl-Fc. The upper chambers were placed into 6-well culture dishes containing $1 \mathrm{ml}$ of medium with $50 \mathrm{ng} / \mathrm{ml}$ human EGF as chemoattractant. After $24 \mathrm{~h}$ of incubation at $37^{\circ} \mathrm{C}$, non-invading cells were removed mechanically using cotton swabs, and the micro-porous membrane containing the invaded cells was stained with DiffQuick solution. In the experiment reported (A) the cells were treated with $\mathrm{H}_{2} \mathrm{O}_{2} 1 \mu \mathrm{M}$ and $(\mathrm{B})$ the cells were treated with NAC $20 \mathrm{mM}$ or NDGA $5 \mu \mathrm{M}$. In the experiment reported (C) the cells were previously transfected with Rac wt, Rac V12 and Rac N17. Chemotaxis was evaluated by counting the cells that had migrated to the lower surface of the polycarbonate filters. For each filter the number of cells in ten randomly chosen fields was determined, and the average and SD were then calculated. ${ }^{*} p<0.005$ vs control (untreated cells for experiment $A$ and $B$ and EGF-stimulated cells for experiment $C$ ); ${ }^{*} p<0.001$ vs control (untreated cells for experiment $A$ and $B$ and EGF-stimulated cells for experiment C). Transfection efficiency of Rac mutants was evaluated by Western blot.

may be an integration point in the cross-talk between ephrinA1 and integrin signaling. We first analyzed p190RhoGAP phosphorylation in response to ephrinA1 and observed an initial increase in its phosphorylation after $5 \mathrm{~min}$ of stimulation (Fig. 7A). The sensitivity to the Src inhibitor PP2 of this early phosphorylation (data not shown) suggests an early involvement of this kinase in ephrinA1/ EphA2 signaling. Afterwards, p190RhoGAP is strongly dephosphorylated. The concomitance between p190RhoGAP dephosphorylation and LMW-PTP reduction/activation by ephrinA1/EphA2 signaling, suggests that this phosphatase plays a role in p190RhoGAP dephosphorylation. This idea was confirmed by the abolition of LMW-PTP expression by RNA interference: we observed that in the absence of LMW-PTP, the phosphorylation level of p190RhoGAP persists also at 15 and 30 minutes of stimulation (Fig. 7B). The involvement of redox signaling is further confirmed by $\mathrm{H}_{2} \mathrm{O}_{2}$ treatment of ephrinA1 stimulated cells, where we again observed a persistence of p190RhoGAP phosphorylation (Fig. 7C).

Given the recognized role of phosphorylated p190RhoGAP as a strong inhibitor of RhoA, we analyzed the effect of $\mathrm{H}_{2} \mathrm{O}_{2}$ and antioxidant treatments on ephrinAl-induced activation of the small GTPase RhoA. In agreement with several other reports, ${ }^{16,18}$ we observed that ephrinA1 is able to elicit strong RhoA activation, as indicated by the increase in its GTP-bound form. Hydrogen peroxide treatment, that counteracts the effect of ephrinA1, inhibits RhoA activation, while the addition of antioxidant enhances GTPase activation (Fig. 7D). These results suggest that ephrinA1 acts on cytoskeleton rearrangement through a redox modulation of Rho activity, exerted by a LMW-PTP-mediated dephosphorylation of its inhibitor p190RhoGAP.

\section{DISCUSSION}

A decrease in adhesion strength is a broad outcome of several biological processes, including the destabilization of blood vessel structures during angiogenesis ${ }^{40}$ and the movement and targeting of metastatic cells. ${ }^{41}$ Reducing ECM attachment forces prompts cell rounding and transition towards ameboid cell movement, uniformly generating a rounded yet dynamic cell shape..$^{41}$ Ameboid motility is characterized by weak cell-ECM adhesion, a dependence on movement by Rho/Rock activation and acto-myosin contractile force which squeezes the cell body within the matrix. ${ }^{42}$ Various studies evidence that the adhesive properties of cells are modulated by Eph/ephrin function in many conditions. Both receptor- and ligand-mediated 


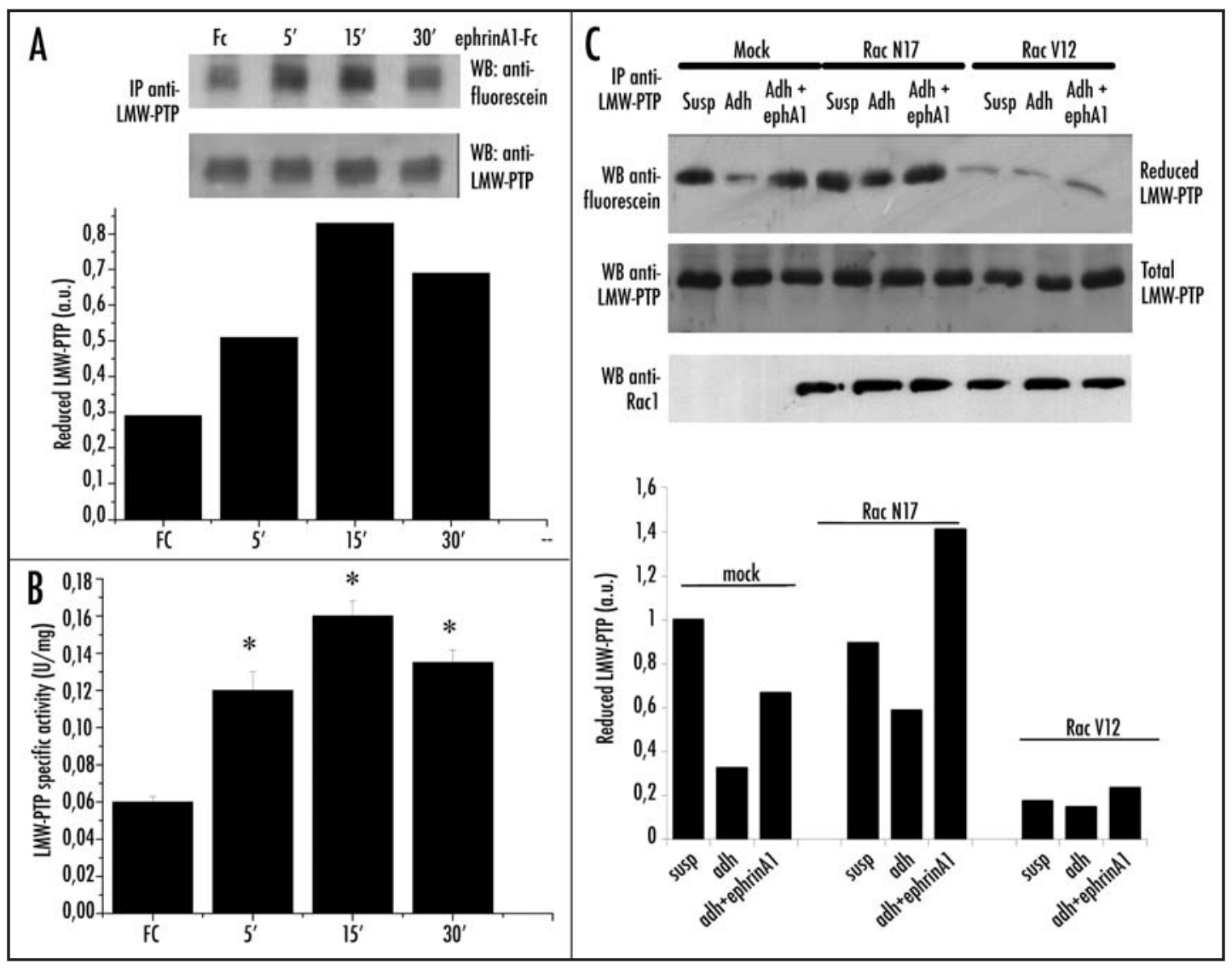

Figure 6. EphrinAl stimulation influences the redox state of LMW-PTP. (A) Evaluation of reduced LMW-PTP during ephrinA 1-Fc stimulation. PC3 cells after 24 hours of starvation were stimulated with ephrinA $1-\mathrm{Fc} 1 \mu \mathrm{g} / \mathrm{ml}$ for the indicated times. Cells were then lysed in the presence of $5 \mathrm{mM} 5$ '-F-IAA. LMW-PTP was immunoprecipitated and its redox state was evidenced by an anti-fluorescein immunoblot. An anti-LMW-PTP immunoblot was also performed for normalization. (B) LMW-PTP activity during ephrinAl stimulation. Cells were treated as in A except that the activity of immunoprecipitated LMW-PTP was quantified by pNPP enzymatic assay. Half of each sample was used in an anti-LMW-PTP immunoblot for normalization and the normalized values obtained in three independent experiments are reported in the plot with SD. ${ }^{*} p<0.001$ vs Fc. (C) Effect of genetic modulation of Rac activity on the redox state of LMW-PTP. Rac wt, Rac V12 and Rac N17 were overexpressed in PC 3 cells. After 24 hours of starvation cells were detached, presuspended for 30 minutes in serum-free medium and kept in suspension or seeded onto FN-coated dishes for 45 minutes with or without ephrinA 1-Fc. Cells were then treated as in (A) and an anti-fluorescein and anti-LMW-PTP were performed.

signaling can regulate adhesion, spreading or migration of various cell types, and accumulating evidence suggests that this effect is mediated through alteration of integrin function. ${ }^{12,43-47}$ For example, EphB2 elicits a de-adhesion signal through the Src-mediated phosphorylation of Tyr 66 of the small GTPase R-Ras, that makes this protein unable to support integrin activity ${ }^{48,49}$ and through the activation of p120RasGAP. ${ }^{19}$ In agreement with previous findings reporting that EphA activation inhibits integrin function in vascular smooth muscle cells and in epithelial cells, ${ }^{12,18}$ we now propose ephrinA1 as a key negative regulator of prostate carcinoma cell adhesion and spreading. In the present study we have shown that the morphological effects of ephrinA1 are associated with inhibition of the small GTPase Rac1. The key role of this GTPase in ephrinA1-mediated inhibition of ECM-adhesion and spreading is supported by the rescuing of effects by constitutive activation of Rac1 or mimicry of integrin inhibition by Rac1 dominant negative. In agreement with this finding Deroanne reported a downregulation of Rac1 during ephrinA1/ EphA2 signaling in vascular smooth cells. ${ }^{18}$

Besides R-Ras modulation of integrin function, we now propose redox regulation of RhoA activation through Racl modulation, as an additional de-adhesion signal elicited by ephrins. An emerging theme in signal transduction by growth factor receptors and adhesion molecules is the role of ROS, and of hydrogen peroxide in particular, as essential downstream messengers modulating cell responses through the transient and reversible oxidation of key intracellular sensitive protein targets. ${ }^{50,51}$ Rac1 signaling has been convincingly shown to contribute to ROS increase during several biological outcomes as mitogenic signaling, ${ }^{52-54}$ survival, ${ }^{55}$ oncogenic H-Ras activation, ${ }^{56,57}$ contact-inhibition of cell growth ${ }^{20}$ and adhesion to ECM. In particular Rac1 activation is a necessary step for optimal focal adhesion assembly and cell spreading. ${ }^{5,11}$ Our data identify the small GTPase Rac1 as a key signaling convergence point between integrin and ephrin cues: upon concomitant stimuli elicited by ephrin and ECM, the small GTPase integrates the multiple signals and consequently affects downstream outcomes. We focus on Rac1-mediated redox signaling and especially on reported redox sensitive targets of integrin signaling. LMW-PTP has been reported to be the target of the Rac1-dependent integrin redox signaling, thereby affecting the downstream tyrosine phosphorylation of its substrate p190RhoGAP. ${ }^{5,11}$ These data identify LMWPTP as the molecular target of integrin-ephrin interplay, as ephrinA1 stimulation prevents LMW-PTP oxidation/inactivation through integrin-elicited Rac/ROS signaling, thereby maintaining its tyrosine phosphatase activity and providing p190RhoGAP dephosphorylation. 


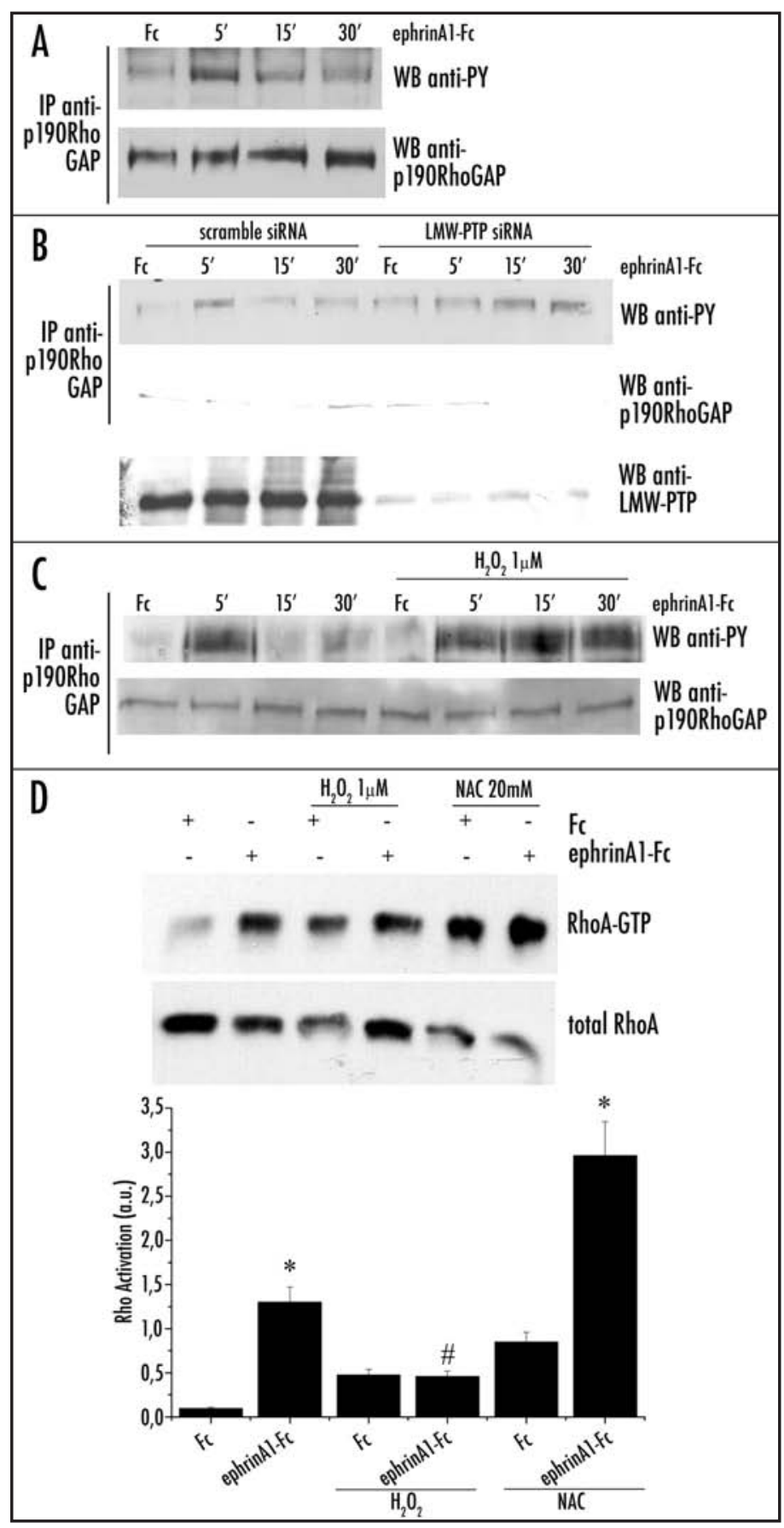

p190RhoGAP is a negative regulator of RhoA, reportedly involved in activation of RhoA due to cell contact with integrin receptors. ${ }^{11,58}$ In keeping, we found a strong correlation between redox regulation of p190RhoGAP from ephrinA1 and the activation of the small GTPase RhoA. Several studies have demonstrated the ability of Eph receptors to activate different Rho-GTPases. ${ }^{59-61}$ Beside RhoGAPs, the effects of Eph receptors on Rho GTPases can either be mediated through recruitment and/or activation of RhoGEFs, which promote exchange of GDP with GTP and activation of RhoGTPases. For example, ephrin-A5 induces growth cone collapse in a RhoA-dependent manner in retinal ganglion cells through recruitment and activation of the RhoGEF ephexin. ${ }^{16}$ In rat vascular smooth muscle cells, EphA4 receptor activates RhoA through the recruitment of another RhoGEF, Vms-RhoGEF. ${ }^{62}$
Figure 7. Role of redox signaling in 190RhoGAP phosphorylation during ephrinAl stimulation. (A) After 24 hours of starvation PC3 cells were stimulated with $1 \mu \mathrm{g} / \mathrm{ml}$ ephrinA $1-F c$ for the indicated periods. Cells were then lysed in RIPA buffer and p190RhoGAP was immunoprecipitated. Anti-phosphotyrosine (4G10) and anti-p190RhoGAP immunoblots were performed. (B) Effect of LMW-PTP RNA interfering on p190RhoGAP phosphorylation: cells were treated as in $A$ except for the presence of $\mathrm{H}_{2} \mathrm{O}_{2}$ $1 \mu \mathrm{M}$ (to promote the oxidation/inactivation of LMW-PTP). (C) Effect of $\mathrm{H}_{2} \mathrm{O}_{2}$ on p190RhoGAP phosphorylation: PC3 cells were transfected with LMW-PTP siRNA or scrambled siRNA and then treated as in (A). A western blot with anti-LMW-PTP specific antibodies was performed on cell lysates to check the silencing of the protein. D) Rho activity assay during ephrinAl/ EphA2 signaling: PC3 cells, after 24 hours of starvation, were stimulated with ephrinA $1-\mathrm{Fc}$ in the presence or not of $\mathrm{H}_{2} \mathrm{O}_{2} 1 \mu \mathrm{M}$. To create reducing conditions PC 3 cells were pretreated with $20 \mathrm{mM}$ NAC for 20 minutes, and then stimulated with ephrinA1-Fc. Cells were then lysed in RIPA buffer and RhoGTP was analyzed by a pull-down assay with Rhotekin-GST-agarose beads ( $B$ and $D)$. A western blot with anti-RhoA specific antibodies was performed on cell lysates for normalization. The values of Rho activation obtained in four independent experiments are reported in the graph. The SD is indicated. " $p<0.001$ vs Fc of the same treatment; ${ }^{*} p<0.005$ vs Fc of the same treatment.

Although for many other Ephs the mechanism for RhoA activation remains to be established, ${ }^{47,63-65}$ for EphB4 an indirect mechanism involving inhibition of R-Ras has been proposed. ${ }^{19}$ Our data identify p190RhoGAP as involved in late ephrinA1/EphA2 signaling, and we propose that redox signaling, mediated by LMW-PTP dephosphorylation of the GAP, is responsible for inactivation of the negative regulator of RhoA. We propose that this effect is responsible for the activation of the GTPase Rho by ephrinA1, although the concomitant activation, probably redox independent, of a GEF for Rho, is highly feasible. Investigations are now in progress to analyze the implications of some of the above mentioned GEF proteins in our model.

In the current model the inhibitory effect of oxidant species on protein tyrosine phosphatases is known to restrain both the strength and duration of growth factor and integrin signalling. ${ }^{66-68}$ Our data now suggest an additional role for ROS: besides their action in the interplay between growth factor and integrin signal transduction, due to positive synergistic modulation of their intracellular content, they also function in the interplay between repulsive/de-adhesive receptors and integrins, thanks to antagonistic modulation of their amount. It is well established that for both proliferative and adhesive signals elicited by growth factors and integrins, the redox regulation of LMW-PTP represents a conserved component of the biochemical machinery triggered by ligands. On the contrary, we now report that during the repulsive/de-adhesive signaling elicited by ephrinA1 the redox regulation which LMW-PTP undergoes is opposite that observed during growth factor or integrin receptor signal transduction, with a transient shift towards the reduced/active form. In our opinion this feature is in agreement with the ability of ephrins to contrast both the proliferative GF-elicited signal and the adhesive integrin-elicited message. ${ }^{12,69,70}$ Once again repulsive Eph receptors behave opposite the proliferative GF-receptors: while "positive" GF-receptors and integrin receptors exert a positive feedback loop based on PTP redox downregulation, that guarantee the proper cytoskeleton dynamics thus allowing cell spreading, the "negative" Eph repulsive receptors set up a negative feedback loop, based on PTP redox upregulation, that impedes the cell spreading mechanisms.

This study provides new insight into the mechanism through which ephrinA1 counteracts integrin signaling, leading to a Rac-mediated upregulation of Rho activity correlated to inhibition of both adhesion 


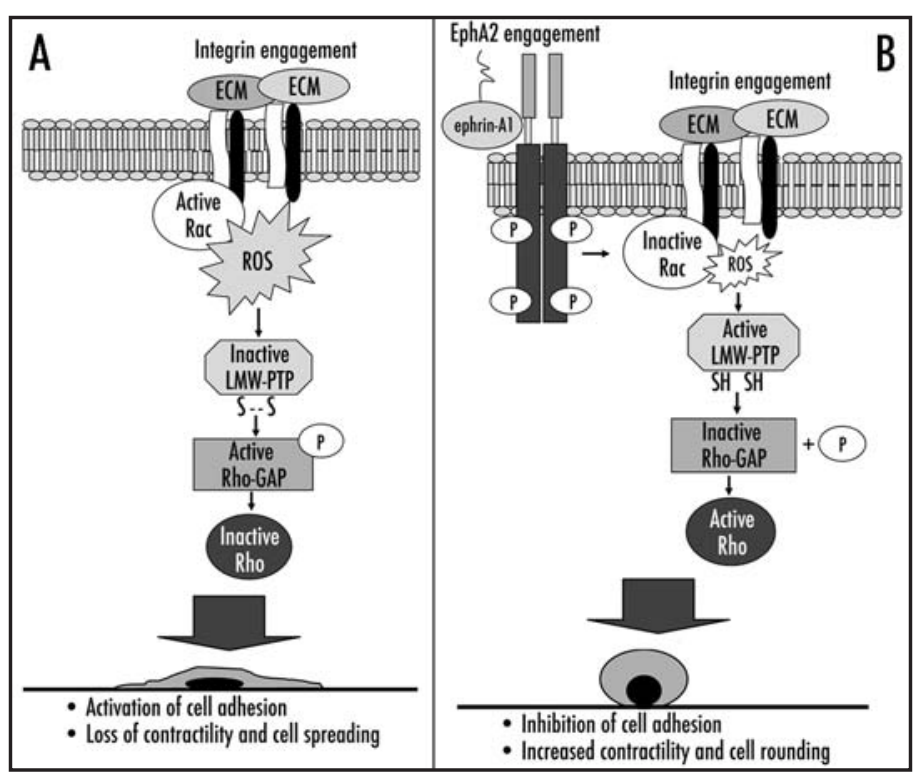

Figure 8. Proposed model of ephrinA1/EphA2 redox circuitry that controls integrin-dependent adhesion. (A) shows the molecular events that contribute to cell adhesion and spreading after integrin engagement; $(B)$ shows the inhibitory effect of ephrinAl/EphA2 signaling leading to inhibition of integrin-dependent adhesion, increased contractility and cell rounding (see text for details).

and spreading onto ECM. These effects elicited by ephrinA1 may exert key regulatory outcomes on cell motility. Cancer cells with rounded morphology usually move through ameboid motility, correlated with increased Rho and decreased Rac activities, ${ }^{41,71}$ whereas well spread cancer cells use a mesenchymal migration mode that depends on Rac activity and is independent on Rho activation. ${ }^{42}$ Thus, ephrinA1 may control the migratory and invasive ability of epithelial cancer cells through inhibition of Rac and consequent redox activation of Rho. In agreement with the possibility that Rac-dependent redox signaling is associated with mesenchymal motility, a clear increase in Rac-dependent redox signals has been established during epithelial-mesenchymal transition, ${ }^{72}$ a process recognized to be linked to Rho inhibition. Up to now there are no available data about the regulation of redox signaling during the shift towards the ameboid motility of cancer cells, a process characterized by the independence from extracellular constraints and from the activity of metalloproteases. ${ }^{71}$ Investigations are now in progress to analyze if ephrinA1 regulation of Rac-mediated redox signaling, through release of integrin function/signaling, can induce a motility shift in prostatic carcinoma cells.

In conclusion the data presented herein lead us to propose a new model for ephrin-mediated downregulation of cell adhesion (Fig. 8). The repulsive ephrinA1/EphA2 signaling inhibits a concomitant integrin-elicited outcome forcing the adhering cell to acquire a rounded Rho-dependent shape. In particular ephrinA1/EphA2 signaling, through downregulation of Rac1-dependent ROS production, prevents the oxidation of LMW-PTP due to integrin ligation, thus guaranteeing the maintenance of its phosphatase activity. The active phosphatase, through the dephosphorylation of p190RhoGAP, leads to sustained Rho activation, which in turn induces cytoskeleton rearrangements leading to cell rounding and thus contrasting integrin-mediated cell adhesion.

\section{Acknowledgements}

This work was supported by the Italian Association for Cancer Research (AIRC), by the Ministero della Università e Ricerca Scientifica e Tecnologica (MIUR-PRIN 2004), by Progetto TRESOR (regione Toscana) and by Cassa di Risparmio di Firenze.

\section{References}

1. Geiger B, Bershadsky A, Pankov R, Yamada KM. Transmembrane crosstalk between the extracellular matrix-cytoskeleton crosstalk. Nat Rev Mol Cell Biol 2001; 2:793-805.

2. Giancotti FG, Ruoslahti E. Integrin signaling. Science 1999; 285:1028-32.

3. Howe A, Aplin AE, Alahari SK, Juliano RL. Integrin signaling and cell growth control. Curr Opin Cell Biol 1998; 10:220-31.

4. Schwartz MA, Ginsberg MH. Networks and crosstalk: Integrin signalling spreads. Nat Cell Biol 2002; 4:E65-8.

5. Chiarugi P, Pani G, Giannoni E, Taddei L, Colavitti R, Raugei G, Symons M, Borrello S, Galeotti T, Ramponi G. Reactive oxygen species as essential mediators of cell adhesion: The oxidative inhibition of a FAK tyrosine phosphatase is required for cell adhesion. J Cell Biol 2003; 161:933-44.

6. Taddei ML, Parri M, Mello T, Catalano A, Levine AD, Raugei G, Ramponi G, Chiarugi P. Integrin-mediated cell adhesion and spreading engage different sources of reactive oxygen species. Antioxid Redox Signal 2007; in press.

7. Fiaschi T, Cozzi G, Raugei G, Formigli L, Ramponi G, Chiarugi P. Redox regulation of beta-actin during integrin-mediated cell adhesion. J Biol Chem 2006; 281:22983-91.

8. Giannoni E, Buricchi F, Raugei G, Ramponi G, Chiarugi P. Intracellular reactive oxygen species activate Src tyrosine kinase during cell adhesion and anchorage-dependent cell growth. Mol Cell Biol 2005; 25:6391-403.

9. Chiarugi P, Cirri P, Taddei L, Giannoni E, Camici G, Manao G, Raugei G, Ramponi G The low $\mathrm{M}(\mathrm{r})$ protein-tyrosine phosphatase is involved in Rho-mediated cytoskeleton rearrangement after integrin and platelet-derived growth factor stimulation. J Biol Chem 2000; 275:4640-46.

10. Honore S, Kovacic H, Pichard V, Briand C, Rognoni JB. Alpha2beta1-integrin signaling by itself controls $\mathrm{G}_{1} / \mathrm{S}$ transition in a human adenocarcinoma cell line (Caco-2): Implication of NADPH oxidase-dependent production of ROS. Exp Cell Res 2003; 285:59-71.

11. Nimnual AS, Taylor LJ, Bar-Sagi D. Redox-dependent downregulation of Rho by Rac. Nat Cell Biol 2003; 5:236-41.

12. Miao H, Burnett E, Kinch M, Simon E, Wang B. Activation of EphA2 kinase suppresses integrin function and causes focal-adhesion-kinase dephosphorylation. Nat Cell Biol 2000; 2:62-9.

13. Parri M, Buricchi F, Taddei ML, Giannoni E, Raugei G, Ramponi G, Chiarugi P. EphrinA1 repulsive response is regulated by an EphA2 tyrosine phosphatase. J Biol Chem 2005; 280:34008-18.

14. Hall A. Rho GTPases and the actin cytoskeleton. Science 1998; 279(5350):509-14.

15. Lawrenson ID, Wimmer-Kleikamp SH, Lock P, Schoenwaelder SM, Down M, Boyd AW, Alewood PF, Lackmann M. Ephrin-A5 induces rounding, blebbing and de-adhesion of EphA3-expressing 293T and melanoma cells by CrkII and Rho-mediated signalling. J Cell Sci 2002; 115:1059-72.

16. Shamah SM, Lin MZ, Goldberg JL, Estrach S, Sahin M, Hu L, Bazalakova M, Neve RL, Corfas G, Debant A, Greenberg ME. EphA receptors regulate growth cone dynamics through the novel guanine nucleotide exchange factor ephexin. Cell 2001; 105:233-44.

17. Wahl S, Barth H, Ciossek T, Aktories K, Mueller BK. Ephrin-A5 induces collapse of growth cones by activating Rho and Rho kinase. J Cell Biol 2000; 149:263-70.

18. Deroanne C, Vouret-Craviari V, Wang B, Pouyssegur J. EphrinA1 inactivates integrin-mediated vascular smooth muscle cell spreading via the Rac/PAK pathway. J Cell Sci 2003; 116:1367-76.

19. Dail M, Richter M, Godement P, Pasquale EB. Eph receptors inactivate R-Ras through different mechanisms to achieve cell repulsion. J Cell Sci 2006; 119:1244-54.

20. Pani G, Colavitti R, Bedogni B, Anzevino R, Borrello S, Galeotti T. A redox signaling mechanism for density-dependent inhibition of cell growth. J Biol Chem 2000; 275:38891-9.

21. Chiarugi P, Fiaschi T, Taddei ML, Talini D, Giannoni E, Raugei G, Ramponi G. Two vicinal cysteines confer a peculiar redox regulation to low molecular weight protein tyrosine phosphatase in response to platelet-derived growth factor receptor stimulation. J Biol Chem 2001; 276:33478-87.

22. Werner E, Werb Z. Integrins engage mitochondrial function for signal transduction by a mechanism dependent on Rho GTPases. J Cell Biol 2002; 158:357-68.

23. Cool RH, Merten E, Theiss C, Acker H. Rac1, and not Rac2, is involved in the regulation of the intracellular hydrogen peroxide level in HepG2 cells. Biochem J 1998; 332:5-8.

24. Diebold BA, Bokoch GM. Molecular basis for Rac2 regulation of phagocyte NADPH oxidase. Nat Immunol 2001; 2:211-15.

25. Miao H, Nickel CH, Cantley LG, Bruggeman LA, Bennardo LN, Wang B. EphA kinase activation regulates HGF-induced epithelial branching morphogenesis. J Cell Biol 2003; 162:1281-92.

26. Chiarugi P, Pani G, Giannoni E, Taddei L, Colavitti R, Raugei G, Symons M, Borrello S, Galeotti T, Ramponi G. Reactive oxygen species as essential mediators of cell adhesion: The oxidative inhibition of a FAK tyrosine phosphatase is required for cell adhesion. J Cell Biol 2003; 161:933-44 
27. Sundaresan M, Yu ZX, Ferrans VJ, Irani K, Finkel T. Requirement for generation of $\mathrm{H}_{2} \mathrm{O} 2$ for platelet-derived growth factor signal transduction. Science 1995; 270:296-9.

28. Finkel T. Reactive oxygen species and signal transduction. IUBMB Life 2001; 52(1-2):3-6.

29. Cunnick JM, Dorsey JF, Mei L, Wu J. Reversible regulation of SHP-1 tyrosine phosphatase activity by oxidation. Biochem Mol Biol Int 1998; 45(5):887-94.

30. Denu JM, Tanner KG. Redox regulation of protein tyrosine phosphatases by hydrogen peroxide: Detecting sulfenic acid intermediates and examining reversible inactivation. Methods Enzymol 2002; 348:297-305.

31. Lee SR, Kwon KS, Kim SR, Rhee SG. Reversible inactivation of protein-tyrosine phosphatase 1B in A431 cells stimulated with epidermal growth factor. J Biol Chem 1998; 273:15366-72.

32. Lee SR, Yang KS, Kwon J, Lee C, Jeong W, Rhee SG. Reversible inactivation of the tumor suppressor PTEN by H2O2. J Biol Chem 2002; 277:20336-42.

33. Rigacci S, Rovida E, Sbarba PD, Berti A. Low Mr phosphotyrosine protein phosphatase associates and dephosphorylates p125 focal adhesion kinase, interfering with cell motility and spreading. J Biol Chem 2002; 277:41631-6.

34. Kikawa KD, Vidale DR, Van Etten RL, Kinch MS. Regulation of the EphA2 kinase by the low molecular weight tyrosine phosphatase induces transformation. J Biol Chem 2002 277:39274-9.

35. Kim JR, Yoon HW, Kwon KS, Lee SR, Rhee SG. Identification of proteins containing cysteine residues that are sensitive to oxidation by hydrogen peroxide at neutral $\mathrm{pH}$. Anal Biochem 2000; 283:214-21.

36. Chiarugi P. The redox regulation of LMW-PTP during cell proliferation or growth inhibition. IUBMB Life 2001; 52:55-9.

37. Bishop AL, Hall A. Rho GTPases and their effector proteins. Biochem J 2000; 348):241-55.

38. Ridley AJ. Rho family proteins: Coordinating cell responses. Trends Cell Biol 2001; 11:471-7.

39. Schmitz AA, Govek EE, Bottner B, Van Aelst L. Rho GTPases: Signaling, migration, and invasion. Exp Cell Res 2000; 261:1-12.

40. Yancopoulos GD, Davis S, Gale NW, Rudge JS, Wiegand SJ, Holash J. Vascular-specific growth factors and blood vessel formation. Nature 2000; 407:242-8.

41. Friedl P. Prespecification and plasticity: Shifting mechanisms of cell migration. Curr Opin Cell Biol 2004; 16:14-23.

42. Yamazaki D, Kurisu S, Takenawa T. Regulation of cancer cell motility through actin reorganization. Cancer Sci 2005; 96:379-86.

43. Bruckner K, Klein R. Signaling by Eph receptors and their ephrin ligands. Curr Opin Neurobiol 1998; 8:375-82.

44. Davy A, Gale NW, Murray EW, Klinghoffer RA, Soriano P, Feuerstein C, Robbins SM Compartmentalized signaling by GPI-anchored ephrin-A5 requires the Fyn tyrosine kinase to regulate cellular adhesion. Genes Dev 1999; 13:3125-35.

45. Davy A, Robbins SM. Ephrin-A5 modulates cell adhesion and morphology in an integrin-dependent manner. EMBO J 2000; 19:5396-405.

46. Huynh-Do U, Stein E, Lane AA, Liu H, Cerretti DP, Daniel TO. Surface densities of ephrin-B1 determine EphB1-coupled activation of cell attachment through alphavbeta3 and alpha5beta1 integrins. EMBO J 1999; 18:2165-73.

47. Miao H, Strebhardt K, Pasquale EB, Shen TL, Guan JL, Wang B. Inhibition of integrin-mediated cell adhesion but not directional cell migration requires catalytic activity of EphB3 receptor tyrosine kinase: Role of Rho family small GTPases. J Biol Chem 2005; 280:923-32.

48. Zou JX, Wang B, Kalo MS, Zisch AH, Pasquale EB, Ruoslahti E. An Eph receptor regulates integrin activity through R-Ras. Proc Natl Acad Sci USA 1999; 96:13813-8.

49. Zou JX, Liu Y, Pasquale EB, Ruoslahti E. Activated $S R C$ oncogene phosphorylates $R$-ras and suppresses integrin activity. J Biol Chem 2002; 277:1824-7.

50. Finkel T. Oxygen radicals and signaling. Curr Opin Cell Biol 1998; 10:248-53.

51. Rhee SG, Bae YS, Lee SR, Kwon J. Hydrogen peroxide: A key messenger that modulates protein phosphorylation through cysteine oxidation. Sci STKE 2000; 2000:E1.

52. Bae YS, Kang SW, Seo MS, Baines IC, Tekle E, Chock PB, Rhee SG. Epidermal growth factor (EGF)-induced generation of hydrogen peroxide: Role in EGF receptor-mediated tyrosine phosphorylation. J Biol Chem 1997; 272:217-21.

53. Colavitti R, Pani G, Bedogni B, Anzevino R, Borrello S, Waltenberger J, Galeotti T. Reactive oxygen species as downstream mediators of angiogenic signaling by vascular endothelial growth factor receptor-2/KDR. J Biol Chem 2002; 277:3101-8.

54. Sundaresan M, Yu ZX, Ferrans VJ, Irani K, Finkel T. Requirement for generation of $\mathrm{H} 2 \mathrm{O} 2$ for platelet-derived growth factor signal transduction. Science 1995; 270:296-9.

55. Bedogni B, Pani G, Colavitti R, Riccio A, Borrello S, Murphy M, Smith R, Eboli ML, Galeotti T. Redox regulation of cAMP-responsive element-binding protein and induction of manganous superoxide dismutase in nerve growth factor-dependent cell survival. J Biol Chem 2003; 278:16510-9.

56. Irani K. Oxidant signaling in vascular cell growth, death, and survival: A review of the roles of reactive oxygen species in smooth muscle and endothelial cell mitogenic and apoptotic signaling. Circ Res 2000; 87:179-83.

57. Liu R, Li B, Qiu M. Elevated superoxide production by active H-ras enhances human lung WI-38VA-13 cell proliferation, migration and resistance to TNF-alpha. Oncogene 2001; 20:1486-96.

58. Arthur WT, Petch LA, Burridge K. Integrin engagement suppresses RhoA activity via a c-Src-dependent mechanism. Curr Biol 2000; 10:719-22.
59. Cowan CW, Shao YR, Sahin M, Shamah SM, Lin MZ, Greer PL, Gao S, Griffith EC, Brugge JS, Greenberg ME. Vav family GEFs link activated Ephs to endocytosis and axon guidance. Neuron 2005; 46:205-17.

60. Noren NK, Lu M, Freeman AL, Koolpe M, Pasquale EB. Interplay between EphB4 on tumor cells and vascular ephrin-B2 regulates tumor growth. Proc Natl Acad Sci USA 2004; 101:5583-8.

61. Sahin M, Greer PL, Lin MZ, Poucher H, Eberhart J, Schmidt S, Wright TM, Shamah SM, O'connell S, Cowan CW, Hu L, Goldberg JL, Debant A, Corfas G, Krull CE, Greenberg ME. Eph-dependent tyrosine phosphorylation of ephexin 1 modulates growth cone collapse. Neuron 2005; 46:191-204.

62. Ogita H, Kunimoto S, Kamioka Y, Sawa H, Masuda M, Mochizuki N. EphA4-mediated Rho activation via Vsm-RhoGEF expressed specifically in vascular smooth muscle cells. Circ Res 2003; 93:23-31.

63. Moeller ML, Shi Y, Reichardt LF, Ethell IM. EphB receptors regulate dendritic spine morphogenesis through the recruitment/phosphorylation of focal adhesion kinase and RhoA activation. J Biol Chem 2006; 281:1587-98.

64. Ogawa K, Wada H, Okada N, Harada I, Nakajima T, Pasquale EB, Tsuyama S. EphB2 and ephrin-B1 expressed in the adult kidney regulate the cytoarchitecture of medullary tubule cells through Rho family GTPases. J Cell Sci 2006; 119:559-70.

65. Tanaka M, Kamo T, Ota S, Sugimura H. Association of Dishevelled with Eph tyrosine kinase receptor and ephrin mediates cell repulsion. EMBO J 2003; 22:847-58.

66. Chiarugi P, Cirri P. Redox regulation of protein tyrosine phosphatases during receptor tyrosine kinase signal transduction. Trends Biochem Sci 2003; 28:509-14.

67. Xu D, Rovira II, Finkel T. Oxidants painting the cysteine chapel: Redox regulation of PTPs. Dev Cell 2002; 2:251-2.

68. Chiarugi P, Buricchi F. Phosphorylation and reversible oxidation: Two cross-talking post-translation modifications. Antioxid Redox Signal 2007; 9:1-24.

69. Elowe S, Holland SJ, Kulkarni S, Pawson T. Downregulation of the Ras-mitogen-activated protein kinase pathway by the EphB2 receptor tyrosine kinase is required for ephrin-induced neurite retraction. Mol Cell Biol 2001; 21:7429-41.

70. Miao H, Wei BR, Peehl DM, Li Q, Alexandrou T, Schelling JR, Rhim JS, Sedor JR, Burnett E, Wang B. Activation of EphA receptor tyrosine kinase inhibits the Ras/MAPK pathway. Nat Cell Biol 2001; 3:527-30.

71. Wolf K, Mazo I, Leung H, Engelke K, von Andrian UH, Deryugina EI, Strongin AY, Brocker EB, Friedl P. Compensation mechanism in tumor cell migration: Mesenchymal-amoeboid transition after blocking of pericellular proteolysis. J Cell Biol 2003; 160:267-77.

72. Radisky DC, Levy DD, Littlepage LE, Liu H, Nelson CM, Fata JE, Leake D, Godden EL, Albertson DG, Nieto MA, Werb Z, Bissell MJ. Rac1b and reactive oxygen species mediate MMP-3-induced EMT and genomic instability. Nature 2005; 436:123-7. 